\title{
Decomposition of Organic Matter in Caves
}

\author{
Nynne Rand Ravn', Anders Michelsen ${ }^{2}$ and Ana Sofia P. S. Reboleira ${ }^{1,3 *}$ \\ ${ }^{1}$ Natural History Museum of Denmark, University of Copenhagen, Copenhagen, Denmark, ${ }^{2}$ Department of Biology, \\ University of Copenhagen, Copenhagen, Denmark, ${ }^{3}$ Centre for Ecology, Evolution and Environmental Changes (cE3c), \\ Departamento de Biologia Animal, Faculdade de Ciências, Universidade de Lisboa, Lisbon, Portugal
}

Decomposition of organic matter is a process, which includes mostly physical breakdown and biochemical transformation of complex organic molecules into simpler organic and inorganic molecules. The decomposition of organic matter is an important contributor to ecosystem respiration, which together with photosynthesis controls the net carbon emission from ecosystems. Subterranean ecosystems are extended all over the subsurface of our planet, and lack of light and consequently of photosynthetic activity. Understanding the drivers that control the dynamics of the decomposition processes in the deep subterranean spaces is important because they might differ from those at surface, due to factors as low species diversity and abundance, low microbial biomass, nutrient poor conditions, less pronounced variation of temperature, and higher humidity inside cave. Here, we review the existing studies of organic matter decomposition in caves. Decomposition rates are known from only nine caves

Edited by: Bradley S. Case, Auckland University of Technology, New Zealand

Reviewed by: Alexander D. Huryn, The University of Alabama,

United States

Andreas Bruder,

University of Applied Sciences and Arts of Southern Switzerland

(SUPSI), Switzerland

*Correspondence:

Ana Sofia P. S. Reboleira sreboleira@snm.ku.dk; asreboleira@fc.ul.pt

Specialty section: This article was submitted to Models in Ecology and Evolution, a section of the journal Frontiers in Ecology and Evolution

Received: 22 April 2020 Accepted: 22 September 2020

Published: 14 October 2020

Citation:

Ravn NR, Michelsen A and Reboleira ASPS (2020) Decomposition of Organic Matter in Caves. Front. Ecol. Evol. 8:554651. doi: 10.3389/fevo.2020.554651 representing four biogeographic regions, including Europe, North and South America. Most of the studies were performed in the aquatic compartment of caves. The decay of nine different organic substrates have been followed and the incubation time varied from 36 to 439 days. From a cave located in Australia the mass loss of leaf material from three plant species was investigated after 9 days incubation in the terrestrial compartment of the cave. Based on these observations, litter quality seems to be an important driver of decomposition in caves, and invertebrates have a stimulating effect on the decomposition within individual cave zones. The degree of connection to the surface also influences decomposition rate inside the cave. The lack of standard data among the studies is currently the major impediment to evaluate how differently the process proceeds in the underground compared to the surface, and to disentangle the main drivers of decomposition in caves across biomes. Improving our understanding of organic matter decomposition dynamics in caves will require the standardization of protocols and evaluation of the process over space and time, and a better comprehension on how decomposition changes over latitudinal, altitudinal and depth gradients.

Keywords: organic matter, leaf litter, decomposition, subterranean ecosystems, cave ecosystems

\section{INTRODUCTION}

The process of organic matter decomposition is a vital element of energy and nutrient cycling in the ecosystem food web and a huge contributor to ecosystem respiration (Smith and Smith, 2012). Carbon is the backbone of life on Earth, and decomposer organisms obtain their energy by oxidation of the carbon compounds (Smith and Smith, 2012). Most of the nutrients required 
by the organisms are also made available during the decomposition process. Thus, the transport of organic matter and its decomposition redistributes energy and nutrients in and between ecosystems (Smith and Smith, 2012).

Together with primary production, the decomposition process determines the amount of soil organic carbon (SOC) in the ecosystem and contributes to the total ecosystem respiration determining the net emission of carbon dioxide $\left(\mathrm{CO}_{2}\right)$ from the ecosystem to the atmosphere (Olson, 1963). The rate and dynamics of organic matter and litter decomposition is hence of huge importance in the context of nutrient and carbon dynamics, global carbon cycle and climate feedback (Heimann and Reichstein, 2008).

The process of organic matter decomposition includes the physical breakdown of substrate and the biochemical transformation of complex organic molecules into simpler organic and inorganic molecules (Chapin et al., 2011). The physical breakdown follows for instance, detritivore-mediated fragmentation and consumption which increases the substrate surface and contributes to the pool of fine particular organic matter, with no alteration of the substrate at the molecular level. The biochemical transformation also occurs during the digestion by invertebrates but also in external substrates. The process is primarily a result of microbial processes and hence often referred to as microbial decomposition (Chapin et al., 2011).

The main biotic and abiotic drivers of organic matter decomposition have been mostly studied in terrestrial and aquatic ecosystems in surface ecosystems (Zhang et al., 2008, 2019; Shah et al., 2017; Djukic et al., 2018), and in comparison, very little is known about the dynamics of decomposition below the ground, in caves.

Decomposition processes in caves are presumably dependent on organic matter input from the outside to sustain the food web within the cave (Culver, 1985; Poulson and Lavoie, 2001). Caves and aquifers differ significantly from surface ecosystems, in their lack of light and consequently of autochthonous photosynthesis-based primary production (Mammola et al., 2019a). Few exceptions are known, comprising caves that rely significantly on primary production at chemolithoautotrophic level (Sarbu et al., 1996; Brankovits et al., 2017). Caves are distributed throughout our planet (Mammola et al., 2019a), and if we want to better understand and make more accurate predictions of carbon emissions to the atmosphere, we should not ignore the contribution of subterranean ecosystems to this process.

Here we provide a critical review on the decomposition of organic matter in caves, and examine the factors that affect rates of decomposition and drivers in caves. We synthesized available data, focusing on the type of organic matter, study sites and experimental conditions, and provide future perspectives for the study of decomposition process in subterranean ecosystems. This constitutes a fundamental starting point for the development of standard methods for estimating global decomposition rates in caves, and for understanding the factors controlling organic matter decay in these hidden ecosystems.

\section{CONTROLLING FACTORS OF DECOMPOSITION}

Specific main drivers of organic matter decomposition in aquatic ecosystems differ from those in terrestrial ecosystems (Boyero et al., 2016; Tiegs et al., 2019) due to environmental differences such as the constant water availability (Gessner et al., 2010; Bruder et al., 2011), and possible oxygen limitations (Medeiros et al., 2009). However, the controlling factors coincide to some extent and are presented below.

\section{Climate}

Temperature and water availability is known to affect the decomposition processes (Conant et al., 2011). Increasing temperature has a direct stimulating effect on microbial and enzymatic activity at least in the short term and increasing the water availability stimulates decomposing microbes by increasing water film on soil particles and hence the diffusion rate (Chapin et al., 2011). Climate conditions in terms of temperature and moisture, e.g., precipitation (Djukic et al., 2018), can explain much of the variation of the decomposition rates in terrestrial surface ecosystems (Berg et al., 1993; Trofymow et al., 2002; Parton et al., 2007). In a study from the northern hemisphere Cornelissen et al. (2007) demonstrated the longerterm and large-scale effects of direct warming on leaf litter decomposition. The major role of climate on litter decomposition was also demonstrated by Garcia-Palacios et al. (2013) in tropical wet forests, deciduous forests and cold or dry biomes. Stimulation of litter decomposition by temperature increase has furthermore been reported from marine environments (Kelaher et al., 2018) and in streams (Shah et al., 2017), and the decomposition of litter in streams can be driven by climate (Boyero et al., 2016).

Despite the recognition of temperature as one of the main drivers of litter decomposition on regional scale, no significant difference between tropical, temperate and cold climate areas was reported when litter decomposition rates were compared in a meta-analysis covering 275 studies of litter decomposition rates in streams (Zhang et al., 2019) and no significant effect of temperature on early stage decomposition was observed in terrestrial ecosystems at the global scale (Djukic et al., 2018). Decomposition rates based in terms of degree-days, have the potential to standardize the temperature effect, allowing a better data comparison across ecosystems (Martínez et al., 2015).

\section{Litter Quality}

There is a general positive linear relationship between plant decomposition rates and nutrient concentrations (Enriquez et al., 1993), as leaf litter with a high nitrogen content has a high nutrient value for the microbes feeding on it (Smith and Smith, 2012). Also the carbon quality of the litter influence the decomposition rates and a substrate containing high concentration of more labile carbon as cellulose and hemicellulose decompose faster compared to substrates with high content of resilient carbon compounds 
as lignin (Chapin et al., 2011). This influence of litter quality on decomposition rates has been reported from marine environments (Apostolaki et al., 2009) and also in streams leaf litter traits were recognized as the driver of litter decomposition rates globally (Handa et al., 2014; Zhang et al., 2019). Also Boyero et al. (2016) concluded that the main part of the variation in litter decomposition was explained by the quality and phylogenetic diversity of the litter. Global scale studies from terrestrial ecosystems have also pointed at litter quality as a main driver of litter decomposition (Heim and Frey, 2004; Cornwell et al., 2008; Bradford et al., 2016) even stronger than climate (Cornwell et al., 2008; Zhang et al., 2008; Makkonen et al., 2012; Garcia-Palacios et al., 2013; Petraglia et al., 2019) but the relative role of climate and litter quality is likely to differ among biomes (Couteaux et al., 1995; Gholz et al., 2000). A recent study used standardized litter substrate, e.g., bags of green tea (high litter quality) and rooibos tea (low litter quality) for a global comparison of litter decomposition mass loss at 336 sites across different terrestrial surface ecosystems (Djukic et al., 2018), concluding that litter quality had a stronger influence on the decomposition in surface ecosystems, in comparison to climatic conditions.

\section{Invertebrates/Detritivores Community}

Another factor influencing litter decomposition rate in terrestrial surface ecosystems is the presence of detritivores (GarciaPalacios et al., 2013), which fragment the litter and graze on the microorganisms, stimulating the microbial activity and increasing the microbial decomposition (Chapin et al., 2011). Their influence has been investigated using exclusion experiments and detritivore effects on decomposition rate seem most important on a regional scale (Wall et al., 2008) and to depend on climate and habitat (Garcia-Palacios et al., 2013). In the marine environment lower rates of decomposition were observed at more sheltered sites (Costa et al., 2019) where invertebrate biomass was low compared to open sea. This effect though was also a result of less mechanical impact. In calcareous streams, the effect of calcium deposition and calcification of leaves potentially influences microbial (and invertebrate) colonization and leaf litter processing, reducing the rate of leaf litter decomposition (Martínez et al., 2015). The invertebrates also play a significant role in litter decomposition in streams (Graca, 2001). When shredders are present in streams, the exclusion of them using mesh bags reduced considerably the litter mass loss. This pattern was further described in a global study by Boyero et al. (2016) as they observed a more pronounced role of litter-consuming detritivores on the decomposition of litter toward high latitudes, where the abundance and diversity of the detritivores was higher. This observation of increased abundance of detritivores in streams toward higher latitude was not evident when synthesized across a bigger but less standardized data set (Shah et al., 2017) but the stimulating effect of detritivores on litter decomposition was clear. Furthermore, the functional diversity of decomposer organisms stimulates the decomposition in terrestrial as well as aquatic ecosystems (Dang et al., 2009; Frainer et al., 2014), but the effect of diversity may depend on season and specific habitats (Frainer et al., 2014).

\section{CAVE ECOSYSTEMS}

Caves are per definition natural underground spaces where humans can fit, and are extended to other voids of the underground hydrogeological network (Lauritzen, 2018). Caves develop mostly in karst (limestone rocks), where the chemical and mechanical interaction with water promotes its development, or in volcanic rocks, where the lava flow or lava retraction forms volcanic caves (Kempe, 2019).

The environmental conditions of caves differ from the surface ecosystems, regarding temperature and humidity conditions (Lauritzen, 2018). The diurnal and seasonal variation of temperature is less pronounced in caves compared to the surface and the humidity is higher (Jones and Macalady, 2016; Lauritzen, 2018).

The total darkness characterizing caves prevents photosynthesis, and with the exception of chemolitho autotrophically based caves (Sarbu et al., 1996; Sarbu, 2001; Engel et al., 2004), primary production is absent (Jones and Macalady, 2016). Therefore, subterranean ecosystems depend on organic matter transport from the surface to maintain heterotrophic productivity (Culver, 1985; Poulson and Lavoie, 2001). Organic matter contains both carbon and nutrient elements, and it comes into caves from allochthonous sources, such as water percolation, or floating into the cave, transport by wind, movement of animals in and out (e.g., bats or swallows) (Simon et al., 2003, 2007; Culver and Pipan, 2009) or in superficial caves by root penetration (Novak et al., 2012; Miller et al., 2020). The volume of organic matter input and the form in which it enters into the caves is dependent on the connection to the surface (Poulson and Lavoie, 2001) and the influx in general is sporadic with high temporal variation (Simon, 2013), and often slow, hence the majority of caves are oligotrophic (Jones and Macalady, 2016). Organic matter is transported into caves as particulate or dissolved organic matter, of which dissolved organic carbon is an important component (Simon et al., 2003). It reaches caves by percolating water (Simon et al., 2007) and during groundwater-surface water mixing in the hyporheic zone (Stegen et al., 2016). Organic carbon in dissolved form is potentially an important source of carbon in cave ecosystems, as it is the case in surface ecosystems (Chapin et al., 2011). Organic matter in particulate form also penetrates into the hyporheic zone (Stegen et al., 2016). Transport of particulate organic matter into caves happens mostly in the form of movement of living animals or plant litter, and in-growth of roots (Simon, 2013).

The cave formation (i.e., speleogenesis) may pose a barrier for the movement of cave-adapted animals, and consequently on energy fluxes (Sendra et al., 2014; Jimenez-Valverde et al., 2017). The cave environment is characterized by environmental constrains that entail dramatic changes in all life forms, and many species have evolved worldwide to be cave exclusive (Christiansen, 2012). Globally, species diversity in caves is limited, as well as their abundance. A cave biodiversity hotspot is considered when it has more than 25 species of terrestrial or aquatic cave animals (Zagmajster et al., 2018). Trophic chains in caves are considered simplified: communities lack photosynthetic primary producers and are typically represented by invertebrates 
adapted to live in subterranean ecosystems with all their life-cycle in the underground, and by an active microbial biomass with an important biogeochemical activity (Mammola et al., 2019a; Summers Engel, 2019).

\section{DECOMPOSITION IN CAVES}

Compared to surface ecosystems, decomposition in caves and their contributing role to the ecosystem carbon cycle and the net ecosystem $\mathrm{CO}_{2}$ emission (Figure 1) remains poorly studied. The main source of organic matter in caves originates from plant material such as litter from surface (Humphreys, 1991), supplemented by carrion (Braack, 1989) and animal droppings as guano (Hamilton-Smith, 2001). As described in the previous section surface organic matter decomposition is controlled by abiotic factors such as temperature, water availability and lack of light alongside with biotic factors such as substrate quality and decomposer community. The subterranean domain influences the abiotic and biotic factors, and hence the decomposition rates and main drivers in caves may differ from what is observed at the surface.

\section{Rates of Decomposition Inside Caves}

A large variability between decomposition rates ( $k_{d}$ values) is observed across caves (Table 1). This reflects differences between cave temperatures, degree-days, aquatic (lotic and lentic systems) and terrestrial compartments of caves, connectivity and distance to the surface, and even more pronounced between the use of different types of organic matter (i.e., substrates). The highest rate of cave decomposition $\left(k_{d}=0.923\right)$ was reported from mouse carcasses placed in a cave stream inside a mesh size that allowed invertebrate access (Huntsman et al., 2011), despite low degreedays values. Lower rates were reported from decomposing red maple leaves in a cave stream, independent of the mesh size of the litter bag (Venarsky et al., 2012) and from pine incubated in the terrestrial compartment of the cave (Hills et al., 2008).

To supplement the decomposition rate $\left(k_{d}\right)$ values reported by the studies from caves that all uses the exponential decay model based on time in days, we estimated decomposition rates $\left(k_{d d}\right)$ using the thermal sums in degree-days (average temperature * incubation time in days) (Bruder et al., 2014). Surprisingly, this normalization for temperature reveals equal decomposition rates $\left(k_{d d}\right)$ of the very different substrates Sorbus aucuparia and Mus musculus in fine mesh. In general, however, animal tissue is more easily decomposed than plant tissue such as leaves, due to lower carbon to nitrogen ratio in the former (Chapin et al., 2011). This is in line with what is observed when comparing the substrates in the coarse mesh bags, the decomposition rates $\left(k_{d d}\right)$ are almost a factor 20 smaller for $S$. aucuparia compared to M. musculus. This suggests an important role of invertebrates for the rate of animal tissue, e.g., mouse decomposition, and also that microorganisms apparently in some cases cannot fully benefit from high resource quality, resulting in similar decomposition rates between the two material in fine mesh bags. This discussion is though based on a limited number of observations. Despite the high difference in degree-days between the two studies using
Quercus alba (Brussock et al., 1988 and Simon and Benfield, 2001) the results of decomposition rate calculations based on degreedays $\left(k_{d d}\right)$ from the study by Brussock et al. (1988) are still most comparable with the rate from the connected 1st order streams (Simon and Benfield, 2001).

Though decomposition rates $\left(k_{d}\right)$ for same leaf species has been studied at surface ecosystems, only few studies concern a direct comparison of cave decomposition rate with the decomposition rate at the surface (Brussock et al., 1988; SouzaSilva et al., 2013). Therefore, it is impossible to uncover clear, general patterns based on the present findings. Because caves are dependent on organic matter from the outside and the temperature partially reflects that of the surface, there might be a link between decomposition rates, despite the higher humidity and the more constant temperature inside the cave compared to the surface.

Common to all previous studies is the lack of standardization of methods to study decomposition rates. Methods vary in terms of substrate, incubation time, sites, availability of the substrate to invertebrates, temperature and calculation of decay rates, which can be standardized to degree-days (Table 1). Although previous studies debate influence of local drivers of decomposition, a general comparison between values and understanding the driving factors of decomposition in caves is currently challenged by the methodological variability across studies.

\section{Terrestrial Cave Decomposition}

Organic matter quality was pointed out as an important driver of decomposition in the terrestrial compartments within caves (Hills et al., 2008), corresponding with what is known from terrestrial surface ecosystems (Heim and Frey, 2004; Cornwell et al., 2008; Bradford et al., 2016; Djukic et al., 2018). This was assessed for differences in litter quality after 3 months of incubation, observing a higher mass loss and decomposition rate of Acer pseudoplatanus leaves (with high specific leaf area) compared to Eucalyptus spp. leaves (with low specific leaf area), a pattern observed in the twilight area (near the cave entrance) as well as in the deepest parts of the cave (Hills et al., 2008). At the cave entrance the higher mass loss of A. pseudoplatanus leaves compared to Eucalyptus spp. leaves is explained by the higher abundance of invertebrates in the bags of A. pseudoplatanus leaves (Hills et al., 2008). A higher accumulation of invertebrates was also associated with a high-quality substrate in rat carrion packages, compared to the invertebrate assemblage in packages of leaf litter (Schneider et al., 2011). It is likely that invertebrates also stimulate decomposition in terrestrial areas of caves, similar to observations in cave streams (Venarsky et al., 2012) and to some extent in terrestrial ecosystems at the surface level (GarciaPalacios et al., 2013). The importance of invertebrates as drivers of litter decomposition in terrestrial cave ecosystems might be very dependent on the site-specific invertebrate abundance, and may differ between cave areas. This match observations of similar mass loss of leaf litter in the twilight zone and the deepest parts of the cave (Hills et al., 2008) and even higher rates of litter decomposition in the deep zone compared to the entrance of the cave (Souza-Silva et al., 2013). This was the case in both studies, despite of a higher occurrence of 


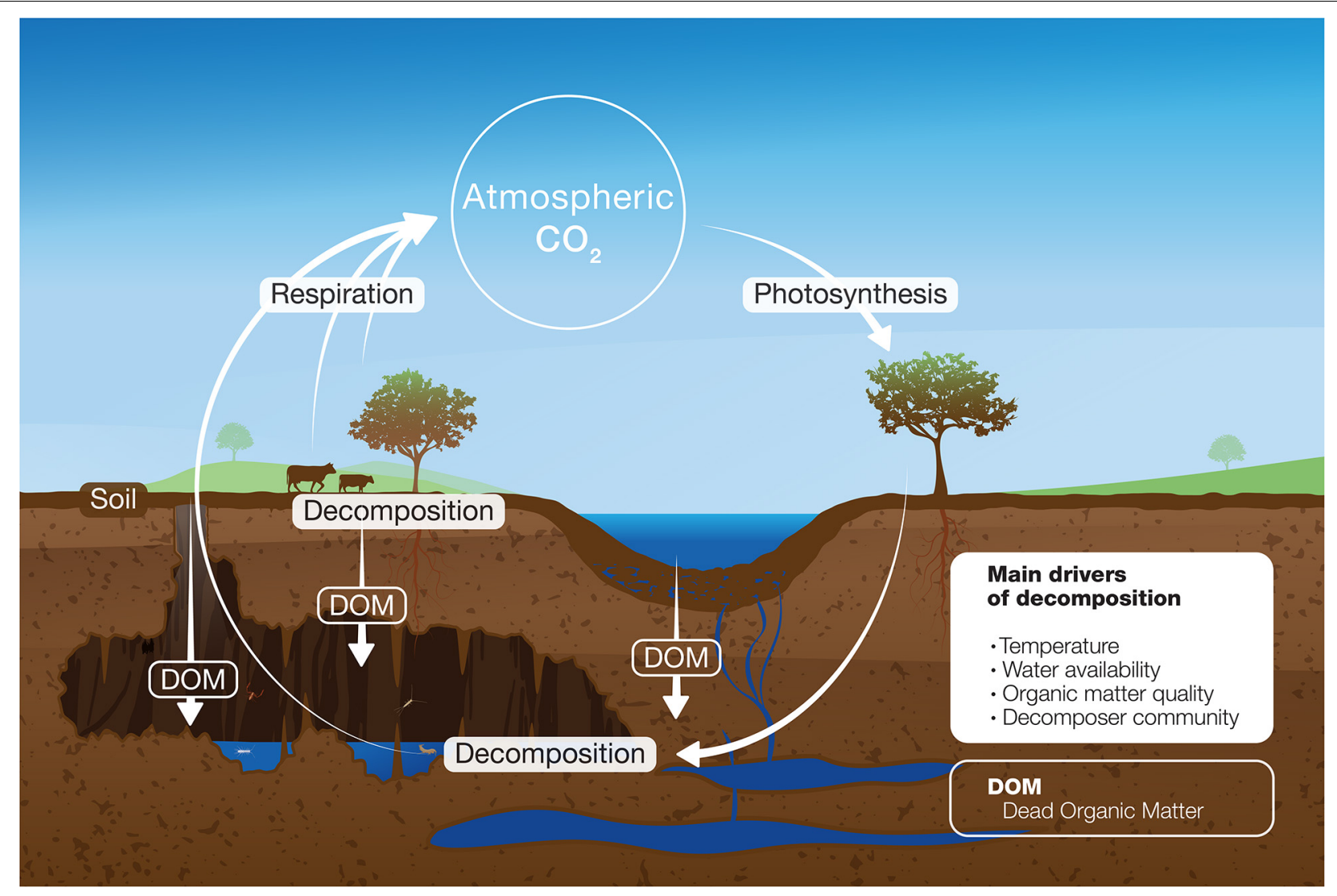

FIGURE 1 | Conceptual model of organic matter decomposition in ecosystems.

invertebrates at the entrance and twilight zone compared to the deepest cave zone. This shows that invertebrate occurrence per se does not explain the variation of the decomposition rates between cave areas. Presumably the deep cave microbial litter decomposition is stimulated by environmental factors such as high humidity and stable temperature which turns out to be some of the drivers of local litter decomposition in terrestrial surface ecosystems (Gonzalez and Seastedt, 2001; Garcia-Palacios et al., 2013). Investigations of the climatic influence on terrestrial cave decomposition are to our knowledge lacking.

\section{Decomposition in Cave Waters}

As is the case in the terrestrial compartments of caves, and at the surface, in cave waters litter quality influences decomposition rates. Higher decomposition rates were measured for high quality corn litter compared to red maple of lower quality in a cave stream (Venarsky et al., 2012), and for Sorbus litter compared to moss, and to Alnus litter in cave waters (Galas et al., 1996). This is in contrast to surface data from a mountain stream in which Alnus leaves were processed faster than leaves of Sorbus (Galas, 1995, 1996). In cave streams Quercus leaf litter and wood appeared to have comparable rates of decomposition, most likely because the Quercus leaf litter was of low quality and the Quercus wood is a veneer with high surface area: volume ratio (Simon and Benfield, 2001).

The role of invertebrates in the decomposition process in cave waters has been investigated in some detail. Venarsky et al. (2012) observed a decrease of the litter decomposition rates due to invertebrate exclusion by containing the litter inside fine mesh bags. The same pattern was not evident in another study that linked the lack of the "invertebrate effect" to the general absence of big shredders in the investigated water pools (Galas et al., 1996). A lab study reported an increase of microbial respiration in the presence of the effective leaf shredder, Gammarus minus (Kinsey et al., 2007), therefore, invertebrates may stimulate also the microbial community to decompose the leaf litter faster. The influence of organic matter abundance has also been suggested to influence the rate of decomposition in cave water, but correlations of environmental organic matter and decomposition rates of added litter (Simon and Benfield, 2001; Venarsky et al., 2012) or carrion (Huntsman et al., 2011) revealed no relationship. Cave connectivity to the surface influenced the decomposition rate of oak litter. Cave streams with larger openings are well connected to the surface water, have a higher input of organic matter, and its invertebrate communities have higher abundance of surface taxa and relatively high decomposition rates (Simon and Benfield, 2001). This was found in comparison to disconnected cave 
TABLE 1 | Available data on decomposition rates in caves.

\begin{tabular}{|c|c|c|c|c|c|c|c|c|c|c|c|}
\hline \multirow[t]{2}{*}{ Cave } & \multirow[t]{2}{*}{ Area } & \multirow[t]{2}{*}{$\begin{array}{l}\text { Cave } \\
\text { compartment }\end{array}$} & \multirow[t]{2}{*}{$\begin{array}{l}\text { Incubation } \\
\text { time } \\
\text { (days) }\end{array}$} & \multirow[t]{2}{*}{$\begin{array}{c}\text { Temperature } \\
\left({ }^{\circ} \mathrm{C}\right)\end{array}$} & \multirow[t]{2}{*}{$\begin{array}{l}\text { Degree-days } \\
\text { above } 0^{\circ} \mathrm{C}\end{array}$} & \multirow[t]{2}{*}{ Substrate } & \multicolumn{2}{|c|}{$\begin{array}{l}\text { Decomposition } \\
\text { rates }\left(\mathbf{k}_{\mathrm{d}}\right) \text { in bags } \\
\text { of dif. mesh size } \\
(\mathbf{m m})\end{array}$} & \multicolumn{2}{|c|}{$\begin{array}{l}\text { Decomposition } \\
\text { rates }\left(\mathbf{k}_{\mathrm{dd}}\right) \text { in } \\
\text { bags of dif. mesh } \\
\text { size }(\mathbf{m m})\end{array}$} & \multirow[t]{2}{*}{ References } \\
\hline & & & & & & & $5-10$ & $0.3-0.5$ & $5-10$ & $0.3-0.5$ & \\
\hline \multirow[t]{2}{*}{ Logan } & $\begin{array}{l}\text { Northwest } \\
\text { Arkansas, } \\
\text { United States }\end{array}$ & A, deep & 65 & $13-15.5$ & 926 & Quercus alba & 0.0075 & & 0.00053 & & Brussock et al., 1988 \\
\hline & & A, below sink hole & & & & & 0.0085 & & 0.00060 & & \\
\hline \multirow[t]{3}{*}{$\begin{array}{l}\text { Kasprowa } \\
\text { Niznia }\end{array}$} & $\begin{array}{l}\text { Western Tatra } \\
\text { Mountains, Poland }\end{array}$ & A & 439 & $4-5$ & 1976 & $\begin{array}{l}\text { Sorbus } \\
\text { aucuparia }\end{array}$ & 0.0031 & 0.0029 & 0.00069 & 0.00064 & Galas et al., 1996 \\
\hline & & & & & & Alnus incana & 0.0013 & 0.0014 & 0.00029 & 0.00031 & \\
\hline & & & & & & Polytrichum sp. & 0.0015 & 0.0016 & 0.00033 & 0.00036 & \\
\hline \multirow[t]{6}{*}{ Jenolan } & $\begin{array}{l}\text { New South Wales, } \\
\text { Australia }\end{array}$ & T, deep & 90 & 15.5 & 1395 & $\begin{array}{l}\text { Acer } \\
\text { pseudoplatanus }\end{array}$ & 0.0053 & & 0.00034 & & Hills et al., 2008 \\
\hline & & T, deep & & & & Pinus radiata & 0.0010 & & 0.00006 & & \\
\hline & & T, deep & & & & Eucalyptus & 0.0017 & & 0.00011 & & \\
\hline & & T, twilight & & & & $\begin{array}{l}\text { Acer } \\
\text { pseudoplatanus }\end{array}$ & 0.0042 & & 0.00027 & & \\
\hline & & $\mathrm{T}$, twilight & & & & Pinus radiata & 0.0008 & & 0.00005 & & \\
\hline & & T, twilight & & & & Eucalyptus & 0.0019 & & 0.00012 & & \\
\hline Tony Sinks & $\begin{array}{l}\text { Alabama, } \\
\text { United States }\end{array}$ & A & 36 & 12.7 & 457 & Mus musculus & 0.1397 & 0.0081 & 0.01100 & 0.00064 & Huntsman et al., 2011 \\
\hline Hering & $\begin{array}{l}\text { Alabama, } \\
\text { United States }\end{array}$ & & & 13 & 468 & & 0.9230 & 0.0098 & 0.07100 & 0.00075 & \\
\hline Jess Elliot & $\begin{array}{l}\text { Alabama, } \\
\text { United States }\end{array}$ & & & 13.3 & 479 & & 0.0247 & 0.0093 & 0.00186 & 0.00070 & \\
\hline Big Mouth & $\begin{array}{l}\text { Tennessee, } \\
\text { United States }\end{array}$ & & & 13.5 & 486 & & 0.4976 & 0.0118 & 0.03686 & 0.00097 & \\
\hline \multirow[t]{2}{*}{ Organ } & $\begin{array}{l}\text { West Virginia, } \\
\text { United States }\end{array}$ & A, disconnected & 261 & 11.5 & 3002 & $\begin{array}{l}\text { Quercus alba } \\
\text { (leaves) }\end{array}$ & 0.0033 & & 0.00029 & & Simon and Benfield, 2001 \\
\hline & & A, disconnected & & & & $\begin{array}{l}\text { Quercus alba } \\
\text { (wood) }\end{array}$ & $\begin{array}{l}0.0040- \\
0.0042\end{array}$ & & $\begin{array}{l}0.00035- \\
0.00037\end{array}$ & & \\
\hline
\end{tabular}


TABLE 1 | Continued

\begin{tabular}{|c|c|c|c|c|c|c|c|c|c|c|c|}
\hline \multirow[t]{2}{*}{ Cave } & \multirow[t]{2}{*}{ Area } & \multirow[t]{2}{*}{$\begin{array}{l}\text { Cave } \\
\text { compartment }\end{array}$} & \multirow[t]{2}{*}{$\begin{array}{l}\text { Incubation } \\
\text { time } \\
\text { (days) }\end{array}$} & \multirow[t]{2}{*}{$\begin{array}{l}\text { Temperature } \\
\left({ }^{\circ} \mathrm{C}\right)\end{array}$} & \multirow[t]{2}{*}{$\begin{array}{l}\text { Degree-days } \\
\text { above } 0^{\circ} \mathrm{C}\end{array}$} & \multirow[t]{2}{*}{ Substrate } & \multicolumn{2}{|c|}{$\begin{array}{l}\text { Decomposition } \\
\text { rates }\left(k_{d}\right) \text { in bags } \\
\text { of dif. mesh size } \\
(\mathbf{m m})\end{array}$} & \multicolumn{2}{|c|}{$\begin{array}{l}\text { Decomposition } \\
\text { rates }\left(\mathbf{k}_{\mathrm{dd} d}\right) \text { in } \\
\text { bags of dif. mesh } \\
\text { size }(\mathbf{m m})\end{array}$} & \multirow[t]{2}{*}{ References } \\
\hline & & & & & & & $5-10$ & $0.3-0.5$ & $5-10$ & $0.3-0.5$ & \\
\hline & & A, connected & & 10.4 & 2714 & $\begin{array}{l}\text { Quercus alba } \\
\text { (leaves) }\end{array}$ & $\begin{array}{l}0.0070- \\
0.0191\end{array}$ & & $\begin{array}{l}0.00067- \\
0.00184\end{array}$ & & \\
\hline & & A, connected & & & & $\begin{array}{l}\text { Quercus alba } \\
\text { (wood) }\end{array}$ & $\begin{array}{l}0.0041- \\
0.0065\end{array}$ & & $\begin{array}{l}0.00039- \\
0.00063\end{array}$ & & \\
\hline & & $\begin{array}{l}\text { A, connected 2nd } \\
\text { order }\end{array}$ & & 9.7 & 2532 & $\begin{array}{l}\text { Quercus alba } \\
\text { (leaves) }\end{array}$ & 0.0259 & & 0.00267 & & \\
\hline & & $\begin{array}{l}\text { A, connected 2nd } \\
\text { order }\end{array}$ & & & & $\begin{array}{l}\text { Quercus alba } \\
\text { (wood) }\end{array}$ & 0.0053 & & 0.00055 & & \\
\hline \multirow[t]{3}{*}{ Casas } & Minas Gerais, Brazil & A & 260 & $14-17$ & 4030 & $\begin{array}{l}\text { Philodendron } \\
\text { sp. }\end{array}$ & $\begin{array}{l}0.0208- \\
0.0277\end{array}$ & & $\begin{array}{l}0.00134- \\
0.00179\end{array}$ & & Souza-Silva et al., 2013 \\
\hline & & T, deep & & 21 & 5460 & & $\begin{array}{l}0.0064- \\
0.0185\end{array}$ & & $\begin{array}{l}0.00030- \\
0.00088\end{array}$ & & \\
\hline & & T, twilight & & 18 & 4680 & & 0.0073 & & 0.00041 & & \\
\hline \multirow[t]{2}{*}{ Tony Sinks } & $\begin{array}{l}\text { Alabama, } \\
\text { United States }\end{array}$ & A & $\sim 183$ & 14 & 2562 & Zea mays & 0.0083 & 0.0034 & 0.00059 & 0.00024 & Venarsky et al., 2012 \\
\hline & & & & & & Acer rubrum & 0.0049 & 0.0015 & 0.00035 & 0.00011 & \\
\hline \multirow[t]{2}{*}{ Jess Elliot } & $\begin{array}{l}\text { Alabama, } \\
\text { United States }\end{array}$ & & & $13-14$ & 2471 & Zea mays & 0.0064 & 0.0028 & 0.00047 & 0.00021 & \\
\hline & & & & & & Acer rubrum & 0.0026 & 0.0014 & 0.00019 & 0.00010 & \\
\hline \multirow[t]{2}{*}{ Salt River } & $\begin{array}{l}\text { Alabama, } \\
\text { United States }\end{array}$ & & & $12-13$ & 2288 & Zea mays & 0.0091 & 0.0029 & 0.00073 & 0.00023 & \\
\hline & & & & & & Acer rubrum & 0.0068 & 0.0014 & 0.00054 & 0.00011 & \\
\hline \multirow[t]{2}{*}{ Big Mouth } & $\begin{array}{l}\text { Tennessee, } \\
\text { United States }\end{array}$ & & & 13 & 2379 & Zea mays & 0.0059 & 0.0022 & 0.00045 & 0.00017 & \\
\hline & & & & & & Acer rubrum & 0.0019 & 0.0011 & 0.00015 & 0.00008 & \\
\hline
\end{tabular}

Decomposition rates $k_{d}$ is estimated based on \% mass loss presented in the manuscript using an exponential decay model: LN (\%mass remaining/100)/time $=-k$ (Petersen and Cummins, 1974). In the studies the $k_{d}$ values has been estimated using an exponential decay model based on mass remaining in dry mass (Brussock et al., 1988; Galas et al., 1996; Hills et al., 2008; Souza-Silva et al., 2013) or ash free dry mass (Simon and Benfield, 2001; Huntsman et al., 2011; Venarsky et al., 2012) and incubation time in days. Additionally, calculations of decomposition rates (kdd) based on degree-days. A, aquatic, T, terrestrial. 
streams that had less organic matter, less surface taxa and lower rates of oak litter decomposition (Simon and Benfield, 2001). The relationship between the organic matter content in caves and decomposition rates seem complex to disentangle and might be influenced by the stimulation of the organic matter abundance in the cave invertebrate community rather than by the organic matter content itself (Simon and Benfield, 2001). The ambient cave organic matter content had little effect on the observed decomposition rate of carrion (Huntsman et al., 2011) and litter (Venarsky et al., 2012).

Leaf litter colonization by microorganisms in cave streams follows the pattern that is typical of surface streams (Simon and Benfield, 2001) and the trophic community structure in many cave streams also appears similar to the surface community structure (Simon et al., 2003). Litter decomposition in cave streams is also to some extent comparable with the process in surface streams but slower rates of decomposition within cave streams have been observed (Brussock et al., 1988; Galas et al., 1996; Venarsky et al., 2012). In the study by Galas et al. (1996) the remarkably slow decomposition rate of nitrogen rich Alnus litter in cave waters might be explained by weak water current and low physical abrasion, and it may also be due to the reduced occurrence of invertebrate shredders (Galas et al., 1996; Venarsky et al., 2012), but other factors might also contribute to the explanation of low decomposition rates in caves streams. For instance, the lower amount of decomposer microbes of all successional stages (Brussock et al., 1988) and the nutrient poor conditions inside the cave compared to the surface (Venarsky et al., 2012) could contribute to the observed differences.

\section{DISCUSSION}

The peculiar environment of the subterranean domain influences both abiotic and biotic factors (Castaño-Sánchez et al., 2020a), hence it is expected that the global decomposition rates and main drivers in caves differ from what is observed at the surface, as it also can differ between surface ecosystems (Couteaux et al., 1995; Datry et al., 2018). Specific conclusions about the major drivers of decomposition in caves and how these may differ from those on surface ecosystems are difficult to predict, based on the current level of knowledge, for two main reasons.

Primarily, all previous studies have a strong geographical bias. Data on decomposition rates and mass loss due to decomposition are only known from ten caves, located in Europe, North and South America, and Australia. Most of these were performed in the aquatic (lotic and lentic) compartment of caves while only three studies focused on the terrestrial compartments of caves, and, to our knowledge, no studies on organic matter decomposition have been performed in anchialine caves (i.e., caves with marine water intrusions). The result shows a huge variation in decomposition rates, likely explained by several differences in the environmental conditions of caves, their connectivity to surface, and the impact of invertebrate activity in the process. Moreover, the variability among experimental conditions between studies complicates comparisons of results, and the possibility to reveal general patterns for decomposition below the ground. But it is clear that there is considerable decomposition of organic matter in caves.

Secondly, the lack of standard data among studies of decomposition in caves and at their correspondent surface is currently the major impediment to evaluate how differently the process occurs below ground compared to at the surface, and to understand if decomposition in caves follows the same patterns as at the surface, across biomes. Despite of the lack of direct comparison, some surface decomposition rates ( $k$ values) for the same litter type are available in the literature, e.g., Q. alba leaf litter at $0.0107-0.0142 \mathrm{~d}^{-1}$ (Griffiths and Tiegs, 2016), which is higher than what was observed in cave streams by Simon and Benfield (2001). Methodological differences especially in the incubation and in mesh size, limit the use of this information to extrapolate general patterns. In the same way, the litter quality of the same species can differ depending on environmental factors (Hansen et al., 2006).

In caves the litter quality seems to be an important driver of decomposition and influences the decomposition rates (Galas et al., 1996; Hills et al., 2008; Venarsky et al., 2012), though the effect in some cases failed to appear (Simon and Benfield, 2001). Because the litter quality is considered as the main driver of decomposition rates at the surface, it is relevant to investigate this in caves where turnover might be affected by a general limitation of labile carbon and nutrient availability. Litter decomposition inside caves might also be influenced by nutrient limitation, because microorganisms can increase the decomposition rate by taking up nitrogen from the surrounding environment (Duddigan et al., 2020), and the oligotrophic conditions inside the cave might decrease the decomposition rate, especially of litter with a high C:N ratio as a result of nitrogen limitation. Hence, differences in the substrate quality might have an even greater influence on decomposition rate inside caves compared to what is observed at the surface. An increase (or a decrease) in the decomposition of the organic matter stored in cave sediments might occur when new substrate is introduced from the surface, the so-called priming effect (Kuzyakov et al., 2000). This might create a variation in the cave decomposition due to the sporadic input of organic matter that are brought into the cave with flowing water, moving animals and wind (Simon et al., 2007; Culver and Pipan, 2009). The priming effect might though be limited inside the cave due to nutrient poor conditions (Hart et al., 1986). The absence of light and photosynthesizing plants inside the cave also restrains the effect of priming in the rhizosphere that might stimulate the decomposition at surface (Kuzyakov et al., 2000; Chapin et al., 2011), resulting in lower decomposition rate inside the cave.

Lower values of microbial biomass carbon inside caves compared to the surface has been reported for caves, e.g., in Brazil (de Paula et al., 2020). Microbial biomass is an important driver of decomposition rates in surface freshwater (Hieber and Gessner, 2002), but the influence on the decomposition 
can also be more affected by the community composition and enzymatic activity than by the microbial biomass alone (Hieber and Gessner, 2002; Chapin et al., 2011). Nutrient limited caves are known to have high microbial diversity (Barton, 2015; Hershey et al., 2018), this diversity may potentially stimulate the decomposition process inside caves. On the other hand, in caves where invertebrates are more abundant, we expect the decomposition to be stimulated by their physical breakdown of substrates (Chapin et al., 2011). The low invertebrate diversity and abundance in caves compared to surface (Mammola et al., 2019a) is likely to affect decomposition to be less driven by invertebrates. All these predictions still need to be tested in cave environments.

The contribution by invertebrates in the decomposer community is considered influential for the decomposition rates inside caves (Hills et al., 2008; Venarsky et al., 2012). The stimulating effect of invertebrates on decomposition is considered a main driver within individual cave zones (Hills et al., 2008). It is therefore important to characterize the diversity and ecological function of the invertebrate communities in caves related to decomposition studies.

A potential "cave-specific" driver of decomposition may be the degree of connectivity to the surface, shown to influence litter decomposition rates (Simon and Benfield, 2001; Simon et al., 2007). This effect needs to be disentangled, as connections to surface may influence several patterns in caves, e.g., the amount of organic matter input, air circulation patterns and consequently the cave communities. Another driver that potentially plays a role in the decomposition in caves is the cave depth, which is known to affect biodiversity distribution patterns inside caves (Sendra and Reboleira, 2012; Trontelj et al., 2019).

Predictions on how the cave environment affects decomposition rates can be suggested based on knowledge from surface ecosystems. It is reasonable to suggest that the cave temperature influences decomposition rates as it does at the surface (Cornelissen et al., 2007; Chapin et al., 2011; GarciaPalacios et al., 2013; Shah et al., 2017; Kelaher et al., 2018), and due to more constant temperature (Jones and Macalady, 2016; Lauritzen, 2018), less seasonal variation of decomposition might occur inside caves. Furthermore, less variation in diurnal temperature reduced mass loss of alder leaves in a study mimicking surface stream conditions (Dang et al., 2009). This is particularly relevant under a climatic change scenario, as the temperature in caves depends on the mean surface temperature and can affect cave-adapted species perniciously (CastañoSánchez et al., 2020a,b). Due to the high relative humidity inside cave we do not expect the terrestrial decomposition in caves to be limited by water availability, as might be the case in dry surface ecosystems (Allison et al., 2013; Petraglia et al., 2019). Hence, increasing temperature might have a higher impact on decomposition inside caves.

Finally, the impacts of human activity in terms of the introduction of non-native plant species on cave decomposition has been investigated by Hills et al. (2008) and indicates that changes in surface vegetation will influence decomposition rate inside caves as a consequence of changes in litter quality. Other effects of human activity such as increased fertilization, heavy metals, and pesticide infiltration into the underground are known to impact cave-adapted organisms (Castaño-Sánchez et al., 2020a), this is likely to trigger a cascade effect and impact also decomposition rates in caves.

\section{FUTURE PERSPECTIVES}

A considerable fraction of decomposition of organic matter on Earth occurs below the ground. Improving our knowledge on this process will allow understanding the differences between surface and subsurface decomposition dynamics, and contribute to a better comprehension of organic matter decomposition dynamics, a fundamental biological process vital to all life on Earth.

The key steps for improving understanding the dynamics of the decomposition process in caves are:

(1) Increasing the knowledge on subterranean ecology: major efforts should be placed in characterizing cave-adapted communities and their functional ecology at global scale, very little is known about the biodiversity patterns of caveadapted species in many regions of our globe (Zagmajster et al., 2018), and these presumably play a major role in stimulating the decomposition process.

(2) Characterization of sources and transport of organic matter in caves: monitoring the flux of detritus, animals and the content and characterization of dissolved organic matter in drip water and streams alongside with an investigation of the sediment inside different caves will contribute to our understanding of dissolved and particulate organic carbon accessibility within caves (Simon et al., 2007; Simon, 2013; Souza-Silva et al., 2013), the quality of the organic matter and sediments in caves, as characterized by the C:N ratio, carbon fractions and the content of dissolved carbon and nutrient elements.

(3) Development of standard methodologies for broad scale studies of decomposition in caves: using the same substrate type and standardization of protocols and evaluation of the process over time, as has been used in freshwater and terrestrial surface ecosystems (Keuskamp et al., 2013; Djukic et al., 2018; Tiegs et al., 2019).

(4) Comparative studies of decomposition between surface and subsurface decomposition: evaluating the differences in decomposition rates, drivers and controls at the surface and below, using the same standard methods.

(5) Identification of specific factors controlling decomposition process in caves: the role of climate and of temperature can be considered by studies in situ in caves at different altitude, latitude and across biomes. The role of cave depth and connection to surface (e.g., large cave entrances) should be evaluated, and lab experiments can inform about the direct effect of temperature and low oscillations of temperature in cave sediments and water under controlled conditions (Dang et al., 2009), which can be supplemented by respiration measurements at different temperatures. This will allow predicting the cave ecosystem 
response to climate change (Heimann and Reichstein, 2008; Mammola et al., 2019b).

While decomposition processes in surface ecosystems is well explored, the parallel processes in caves, and cave contribution to the global carbon cycle and the net ecosystem $\mathrm{CO}_{2}$ emission remains unknown. Caves extend throughout our planet, implying that to make more accurate predictions on carbon emissions to the atmosphere we should not neglect the contribution of these ecosystems to the overall carbon cycle. Caves are unique ecosystems with very specialized communities that are threatened (Castaño-Sánchez et al., 2020a,b) and therefore need to be better understood and protected to ensure their ecosystem functioning niches that add substantially to overall biodiversity of a region.

\section{REFERENCES}

Allison, S. D., Lu, Y., Weihe, C., Goulden, M. L., Martiny, A. C., Treseder, K. K., et al. (2013). Microbial abundance and composition influence litter decomposition response to environmental change. Ecology 94, 714-725. doi: 10.1890/12-1243.1

Apostolaki, E. T., Marba, N., Holmer, M., and Karakassis, I. (2009). Fish farming impact on decomposition of Posidonia oceanica litter. J. Exp. Mar. Biol. Ecol. 369, 58-64. doi: 10.1016/j.jembe.2008.10.022

Barton, H. A. (2015). "Starving artists: bacterial oligotrophic heterotrophy in caves," in Microbial Life of Cave Systems - Life in Extreme Environments, ed. A. Summers Engel (Berlin: Walter de Gruyter $\mathrm{GmbH}$ ).

Berg, B., Berg, M. P., Bottner, P., Box, E., Breymeyer, A., Deanta, R. C., et al. (1993). Litter Mass-Loss Rates in Pine Forests of Europe and Eastern UnitedStates - Some Relationships with Climate and Litter Quality. Biogeochemistry 20, 127-159. doi: 10.1007/Bf00000785

Boyero, L., Pearson, R. G., Hui, C., Gessner, M. O., Perez, J., Alexandrou, M. A., et al. (2016). Biotic and abiotic variables influencing plant litter breakdown in streams: a global study. Proc. R. Soc. B Biol. Sci. 283:20152664. doi: 10.1098/rspb. 2015.2664

Braack, L. E. O. (1989). Arthropod inhabitants of a tropical cave island environment provisioned by bats. Biol. Conserv. 48, 77-84. doi: 10.1016/00063207(89)90027-X

Bradford, M. A., Berg, B., Maynard, D. S., Wieder, W. R., and Wood, S. A. (2016). Understanding the dominant controls on litter decomposition. J. Ecol. 104, 229-238. doi: 10.1111/1365-2745.12507

Brankovits, D., Pohlman, J. W., Niemann, H., Leigh, M. B., Leewis, M. C., Becker, K. W., et al. (2017). Methane- and dissolved organic carbon-fueled microbial loop supports a tropical subterranean estuary ecosystem. Nat. Commun. 8:1835. doi: 10.1038/s41467-017-01776-x

Bruder, A., Chauvet, E., and Gessner, M. O. (2011). Litter diversity, fungal decomposers and litter decomposition under simulated stream intermittency. Funct. Ecol. 25, 1269-1277. doi: 10.1111/j.1365-2435.2011.01903.x

Bruder, A., Schindler, M. H., Moretti, M. S., and Gessner, M. O. (2014). Litter decomposition in a temperate and a tropical stream: the effects of species mixing, litter quality and shredders. Freshw. Biol. 59, 438-449. doi: 10.1111/ fwb. 12276

Brussock, P. P., Willis, L. D., and Brown, A. V. (1988). Leaf Decomposition in an Ozark Cave and Spring. J. Freshw. Ecol. 4, 263-269. doi: 10.1080/02705060.1988. 9665175

Castaño-Sánchez, A., Hose, G. C., and Reboleira, A. S. P. S. (2020a). Ecotoxicological effects of anthropogenic stressors in subterranean organisms: a review. Chemosphere 244:125422. doi: 10.1016/j.chemosphere.2019. 125422

Castaño-Sánchez, A., Hose, G. C., and Reboleira, A. S. P. S. (2020b). Salinity and temperature increase impact groundwater crustaceans. Sci. Rep. 10:12328. doi: 10.1038/s41598-020-69050-7

Chapin, F. S. III, Matson, P. A., and Vitousek, P. M. (2011). Principles of Terrestrial Ecosystem Ecology. 2nd Edn. New York, NY: Springer.

\section{AUTHOR CONTRIBUTIONS}

NR drafted the manuscript. AM participated in the design of the study. AR conceived and coordinated the study, and provided the resources, funding acquisition, project administration, and supervision. All authors contributed to the manuscript production and approved the final version for publication.

\section{FUNDING}

This work was supported by a research grant (15471) from the VILLUM FONDEN, and Carlsbergfondet Research Infrastructure grant (CF19-0609).

Christiansen, K. (2012). "Morphological adaptations," in Encyclopedia of Caves, eds W. B. White and D. C. Culver (Waltham, MA: Academic Press), 517-528.

Conant, R. T., Ryan, M. G., Agren, G. I., Birge, H. E., Davidson, E. A., Eliasson, P. E., et al. (2011). Temperature and soil organic matter decomposition rates - synthesis of current knowledge and a way forward. Glob. Change Biol. 17, 3392-3404. doi: 10.1111/j.1365-2486.2011.02496.x

Cornelissen, J. H. C., van Bodegom, P. M., Aerts, R., Callaghan, T. V., van Logtestijn, R. S. P., Alatalo, J., et al. (2007). Global negative vegetation feedback to climate warming responses of leaf litter decomposition rates in cold biomes. Ecol. Lett. 10, 619-627. doi: 10.1111/j.1461-0248.2007.01051.x

Cornwell, W. K., Cornelissen, J. H. C., Amatangelo, K., Dorrepaal, E., Eviner, V. T., Godoy, O., et al. (2008). Plant species traits are the predominant control on litter decomposition rates within biomes worldwide. Ecol. Lett. 11, 1065-1071. doi: 10.1111/j.1461-0248.2008.01219.x

Costa, V., Mazzola, A., Rossi, F., and Vizzini, S. (2019). Decomposition rate and invertebrate colonization of seagrass detritus along a hydrodynamic gradient in a Mediterranean coastal basin: the Stagnone di Marsala (Italy) case study. Mar. Ecol. Evol. Perspect. 40:e12570. doi: 10.1111/maec.12570

Couteaux, M. M., Bottner, P., and Berg, B. (1995). Litter decomposition, climate and litter quality. Trends Ecol. Evol. 10, 63-66. doi: 10.1016/S0169-5347(00) 88978-8

Culver, D. C. (1985). Trophic relationships in aquatic cave environments. Stygologia 1, 43-53.

Culver, D. C., and Pipan, T. (2009). The Biology of Caves and Other Subterranean Habitats. Oxford: Oxford University Press.

Dang, C. K., Schindler, M., Chauvet, E., and Gessner, M. O. (2009). Temperature oscillation coupled with fungal community shifts can modulate warming effects on litter decomposition. Ecology 90, 122-131. doi: 10.1890/07-1974.1

Datry, T., Foulquier, A., Corti, R., Von Schiller, D., Tockner, K., Mendoza-Lera, C., et al. (2018). A global analysis of terrestrial plant litter dynamics in nonperennial waterways. Nat. Geosci. 11, 497-503.

de Paula, C. C. P., Bichuette, M. E., and Seleghim, M. H. R. (2020). Nutrient availability in tropical caves influences the dynamics of microbial biomass. Microbiologyopen 9:e1044. doi: 10.1002/mbo3.1044

Djukic, I., Kepfer-Rojas, S., Schmidt, I. K., Larsen, K. S., Beier, C., Berg, B., et al. (2018). Early stage litter decomposition across biomes. Sci. Total Environ. 628-629, 1369-1394. doi: 10.1016/j.scitotenv.2018.01.012

Duddigan, S., Shaw, L. J., Alexander, P. D., and Collins, C. D. (2020). Chemical underpinning of the tea bag index: an examination of the decomposition of tea leaves. Appl. Environ. Soil Sci. 2020:6085180. doi: 10.1155/2020/60 85180

Engel, A. S., Porter, M. L., Stern, L. A., Quinlan, S., and Bennett, P. C. (2004). Bacterial diversity and ecosystem function of filamentous microbial mats from aphotic (cave) sulfidic springs dominated by chemolithoautotrophic “Epsilonproteobacteria”. FEMS Microbiol. Ecol. 51, 31-53. doi: 10.1016/j. femsec.2004.07.004

Enriquez, S., Duarte, C. M., and Sand-Jensen, K. (1993). Patterns in decomposition rates among photosynthetic organisms - the importance of Detritus C-N-P Content. Oecologia 94, 457-471. doi: 10.1007/Bf00566960 
Frainer, A., McKie, B. G., and Malmqvist, B. (2014). When does diversity matter? Species functional diversity and ecosystem functioning across habitats and seasons in a field experiment. J. Anim. Ecol. 83, 460-469. doi: 10.1111/13652656.12142

Galas, J. (1995). Alder, Alnus incana [L.] Mnch., leaf decomposition in a high mountain stream. Acta Hydrobiol. 37, 197-203.

Galas, J. (1996). Depositional processes and suspension of particulate organic matter in a high mountain stream above the timber line. Adv. Limnol. 47, 449-454.

Galas, J., Bednarz, T., Dumnicka, E., Starzecka, A., and Wojtan, K. (1996). Litter decomposition in a mountain cave water. Arch. Hydrobiol. 138, 199-211.

Garcia-Palacios, P., Maestre, F. T., Kattge, J., and Wall, D. H. (2013). Climate and litter quality differently modulate the effects of soil fauna on litter decomposition across biomes. Ecol. Lett. 16, 1045-1053. doi: 10.1111/ele.12137

Gessner, M. O., Swan, C. M., Dang, C. K., Mckie, B. G., Bardgett, R. D., Wall, D. H., et al. (2010). Diversity meets decomposition. Trends Ecol. Evol. 25, 372-380. doi: $10.1016 /$ j.tree.2010.01.010

Gholz, H. L., Wedin, D. A., Smitherman, S. M., Harmon, M. E., and Parton, W. J. (2000). Long-term dynamics of pine and hardwood litter in contrasting environments: toward a global model of decomposition. Glob. Change Biol. 6, 751-765. doi: 10.1046/j.1365-2486.2000.00349.x

Gonzalez, G., and Seastedt, T. R. (2001). Soil fauna and plant litter decomposition in tropical and subalpine forests. Ecology 82, 955-964.

Graca, M. A. S. (2001). The role of invertebrates on leaf litter decomposition in streams - A review. Int. Rev. Hydrobiol. 86, 383-393.

Griffiths, N. A., and Tiegs, S. D. (2016). Organic-matter decomposition along a temperature gradient in a forested headwater stream. Fresh w. Sci. 35, 518-533. doi: $10.1086 / 685657$

Hamilton-Smith, E. (2001). Maintenance of karst biodiversity, with an emphasis upon Australian populations. Rec. West. Aust. Mus. 64, 85-95.

Handa, I. T., Aerts, R., Berendse, F., Berg, M. P., Bruder, A., Butenschoen, O., et al. (2014). Consequences of biodiversity loss for litter decomposition across biomes. Nature 509, 218-221. doi: 10.1038/nature13247

Hansen, A. H., Jonasson, S., Michelsen, A., and Julkunen-Tiitto, R. (2006). Long-term experimental warming, shading and nutrient addition affect the concentration of phenolic compounds in arctic-alpine deciduous and evergreen dwarf shrubs. Oecologia 147, 1-11. doi: 10.1007/s00442-005-0233-y

Hart, P. B. S., Rayner, J. H., and Jenkinson, D. S. (1986). Influence of Pool Substitution on the Interpretation of Fertilizer Experiments with N-15. J. Soil Sci. 37, 389-403. doi: 10.1111/j.1365-2389.1986.tb00372.x

Heim, A., and Frey, B. (2004). Early stage litter decomposition rates for Swiss forests. Biogeochemistry 70, 299-313. doi: 10.1007/s10533-003-0844-5

Heimann, M., and Reichstein, M. (2008). Terrestrial ecosystem carbon dynamics and climate feedbacks. Nature 451, 289-292. doi: 10.1038/nature06591

Hershey, O. S., Kallmeyer, J., Wallace, A., Barton, M. D., and Barton, H. A. (2018). High microbial diversity despite extremely low biomass in a deep Karst Aquifer. Front. Microbiol. 9:2823. doi: 10.3389/fmicb.2018.02823

Hieber, M., and Gessner, M. O. (2002). Contribution of stream detrivores, fungi, and bacteria to leaf breakdown based on biomass estimates. Ecology 83, 10261038.

Hills, N., Hose, G. C., Cantlay, A. J., and Murray, B. R. (2008). Cave invertebrate assemblages differ between native and exotic leaf litter. Austral Ecol. 33, 271277. doi: $10.1111 /$ j.1442-9993.2007.01814.x

Humphreys, W. F. (1991). Experimental reestablishment of pulse-driven populations in a terrestrial troglobite community. J. Anim. Ecol. 60, 609-623. doi: $10.2307 / 5301$

Huntsman, B. M., Venarsky, M. P., and Benstead, J. P. (2011). Relating carrion breakdown rates to ambient resource level and community structure in four cave stream ecosystems. J. N. Am. Benthol. Soc. 30, 882-892. doi: 10.1899/10116.1

Jimenez-Valverde, A., Sendra, A., Garay, P., and Reboleira, A. S. P. S. (2017). Energy and speleogenesis: key determinants of terrestrial species richness in caves. Ecol. Evol. 7, 10207-10215. doi: 10.1002/ece3.3558

Jones, D. S., and Macalady, J. L. (2016). "The snotty and the stringy: energy for subsurface life in caves," in Their World: A Diversity of Microbial Environments, Vol. 1, ed. C. Hurstx (Cham: Springer), 203-224. doi: 10.1007/978-3-31928071-4_5
Kelaher, B. P., Coleman, M. A., and Bishop, M. J. (2018). Ocean warming, but not acidification, accelerates seagrass decomposition under near-future climate scenarios. Mar. Ecol. Prog. Ser. 605, 103-110. doi: 10.3354/meps12762

Kempe, S. (2019). "Volcanic rock caves," in Encyclopedia of Caves, 3rd Edn, eds W. B. White, D. C. Culver, and T. Pipan (Cambridge, MA: Academic Press), 1118-1127.

Keuskamp, J. A., Dingemans, B. J. J., Lehtinen, T., Sarneel, J. M., and Hefting, M. M. (2013). Tea Bag Index: a novel approach to collect uniform decomposition data across ecosystems. Methods Ecol. Evol. 4, 1070-1075. doi: 10.1111/2041-210x. 12097

Kinsey, J., Cooney, T. J., and Simon, K. S. (2007). A comparison of the leaf shredding ability and influence on microbial films of surface and cave forms of Gammarus minus say. Hydrobiologia 589, 199-205. doi: 10.1007/s10750-0070739-x

Kuzyakov, Y., Friedel, J. K., and Stahr, K. (2000). Review of mechanisms and quantification of priming effects. Soil Biol. Biochem. 32, 1485-1498. doi: 10. 1016/S0038-0717(00)00084-5

Lauritzen, S. (2018). "Physiography of the Caves," in Cave Ecology, eds O. T. Moldovan, L. Kováč, and S. Halse (Cham: Springer), 7-22.

Makkonen, M., Berg, M. P., Handa, I. T., Hattenschwiler, S., van Ruijven, J., van Bodegom, P. M., et al. (2012). Highly consistent effects of plant litter identity and functional traits on decomposition across a latitudinal gradient. Ecol. Lett. 15, 1033-1041. doi: 10.1111/j.1461-0248.2012.01826.x

Mammola, S., Cardoso, P., Culver, D. C., Deharveng, L., Ferreira, R. L., Flser, C., et al. (2019a). Scientists' warning on the conservation of subterranean ecosystems. Bioscience 69, 641-650. doi: 10.1093/biosci/biz064

Mammola, S., Piano, E., Cardoso, P., Vernon, P., Dominguez-Villar, D., Culver, D. C., et al. (2019b). Climate change going deep: the effects of global climatic alterations on cave ecosystems. Anthropocene Rev. 6, 98-116. doi: 10.1177/ 2053019619851594

Martínez, A., Pérez, J., Molinero, J., Sagarduy, M., and Pozo, J. (2015). Effects of flow scarcity on leaf-litter processing under oceanic climate conditions in calcareous streams. Sci. Total Environ. 503, 251-257. doi: 10.1016/j.scitotenv. 2014.06.018

Medeiros, A. O., Pascoal, C., and Graca, M. A. S. (2009). Diversity and activity of aquatic fungi under low oxygen conditions. Freshw. Biol. 54, 142-149. doi: 10.1111/j.1365-2427.2008.02101.x

Miller, A. Z., De la Rosa, J. M., Jimenez-Morillo, N. T., Pereira, M. F. C., GonzalezPerez, J. A., Knicker, H., et al. (2020). Impact of wildfires on subsurface volcanic environments: new insights into speleothem chemistry. Sci. Total Environ. 698:134321. doi: 10.1016/j.scitotenv.2019.134321

Novak, T., Perc, M., Lipovsek, S., and Janzekovic, F. (2012). Duality of terrestrial subterranean fauna. Int. J. Speleol. 41, 181-188. doi: 10.5038/1827-806x.41.2.5

Olson, J. S. (1963). Energy-storage and balance of producers and decomposers in ecological-systems. Ecology 44, 32-331. doi: 10.2307/1932179

Parton, W., Silver, W. L., Burke, I. C., Grassens, L., Harmon, M. E., Currie, W. S., et al. (2007). Global-scale similarities in nitrogen release patterns during long-term decomposition. Science 315, 361-364. doi: 10.1126/science.11 34853

Petersen, R. C., and Cummins, K. W. (1974). Leaf processing in a woodland stream. Freshw. Biol. 4, 343-368. doi: 10.1111/j.1365-2427.1974.tb00103.x

Petraglia, A., Cacciatori, C., Chelli, S., Fenu, G., Calderisi, G., Gargano, D., et al. (2019). Litter decomposition: effects of temperature driven by soil moisture and vegetation type. Plant Soil 435, 187-200. doi: 10.1007/s11104-018-3889-x

Poulson, T. L., and Lavoie, K. H. (2001). "The trophic basis of subsurface ecosystems," in Ecosystems of the World: Subterranean Ecosystems, eds H. Wilkens, D. C. Culver, and W. F. Humphreys (New York, NY: Elsevier), 231-250.

Sarbu, S. M. (2001). "Movile Cave: a chemoautotrophically based groundwater ecosystem," in Ecosystems of the World: Subterranean Ecosystems, eds H. C. Wilkens, D. C. Culver, and W. F. Humphreys (New York, NY: Elsevier), 319-344.

Sarbu, S. M., Kane, T. C., and Kinkle, B. K. (1996). A chemoautotrophically based cave ecosystem. Science 272, 1953-1955. doi: 10.1126/science.272.5270.1953

Schneider, K., Christman, M. C., and Fagan, W. F. (2011). The influence of resource subsidies on cave invertebrates: results from an ecosystem-level manipulation experiment. Ecology 92, 765-776. doi: 10.1890/10-0157.1 
Sendra, A., Garay, P., Ortuno, V. M., Gilgado, J. D., Teruel, S., and Reboleira, A. S. P. S. (2014). Hypogenic versus epigenic subterranean ecosystem: lessons from eastern Iberian Peninsula. Int. J. Speleol. 43, 253-264. doi: 10.5038/1827806x.43.3.2

Sendra, A., and Reboleira, A. S. P. S. (2012). The world's deepest subterranean community - Krubera-Voronja Cave (Western Caucasus). Int. J. Speleol. 41, 221-230. doi: 10.5038/1827-806x.41.2.9

Shah, J. J. F., Kominoski, J. S., Ardon, M., Dodds, W. K., Gessner, M. O., Griffiths, N. A., et al. (2017). Global synthesis of the temperature sensitivity of leaf litter breakdown in streams and rivers. Glob. Change Biol. 23, 3064-3075. doi: $10.1111 /$ gcb.13609

Simon, K. S. (2013). Organic Matter Flux in the Epikarst of the Dorvan Karst, France. Acta Carsol. 42, 237-244.

Simon, K. S., and Benfield, E. F. (2001). Leaf and wood breakdown in cave streams. J. N. Am. Benthol. Soc. 20, 550-563. doi: 10.2307/14 68087

Simon, K. S., Benfield, E. F., and Macko, S. A. (2003). Food web structure and the role of epilithic biofilms in cave streams. Ecology 84, 2395-2406. doi: 10.1890/ 02-334

Simon, K. S., Pipan, T., and Culver, D. C. (2007). A conceptual model of the flow and distribution of organic carbon in caves. J. Cave Karst Stud. 69, 279-284.

Smith, T. M., and Smith, R. L. (2012). "Decomposition and nutrient cycling," in Elements of Ecology, 8th Edn, ed. B. Wilbur (London: Pearson Education Inc).

Souza-Silva, M., Salvio, A., and Ferreira, R. L. (2013). Food Resource Availability in a Quartzite Cave in the Brazilian Montane Atlantic Forest. J. Cave Karst Stud. 75, 177-188. doi: 10.4311/2010jcks0158

Stegen, J. C., Fredrickson, J. K., Wilkins, M. J., Konopka, A. E., Nelson, W. C., Arntzen, E. V., et al. (2016). Groundwater-surface water mixing shifts ecological assembly processes and stimulates organic carbon turnover. Nat. Commun. 7:11237. doi: $10.1038 /$ ncomms 11237

Summers Engel, A. S. (2019). "Microbes," in Encyclopedia of Caves, eds W. B. White, D. C. Culver, and T. Pipan (Cambridge, MA: Academic Press), 691-698.

Tiegs, S. D., Costello, D. M., Isken, M. W., Woodward, G., McIntyre, P. B., Gessner, M. O., et al. (2019). Global patterns and drivers of ecosystem functioning in rivers and riparian zones. Sci. Adv. 5:eaav0486. doi: 10.1126/sciadv.aav 0486

Trofymow, J. A., Moore, T. R., Titus, B., Prescott, C., Morrison, I., Siltanen, M., et al. (2002). Rates of litter decomposition over 6 years in Canadian forests: influence of litter quality and climate. Can. J. For. Res. Rev. 32, 789-804. doi: 10.1139/X01-117

Trontelj, P., Borko, S., and Delic, T. (2019). Testing the uniqueness of deep terrestrial life. Sci. Rep. 9:15188. doi: 10.1038/s41598-019-51610-1

Venarsky, M. P., Benstead, J. P., and Huryn, A. D. (2012). Effects of organic matter and season on leaf litter colonisation and breakdown in cave streams. Freshw. Biol. 57, 773-786. doi: 10.1111/j.1365-2427.2012.02742.x

Wall, D. H., Bradford, M. A., St John, M. G., Trofymow, J. A., Behan-Pelletier, V., Bignell, D. D. E., et al. (2008). Global decomposition experiment shows soil animal impacts on decomposition are climate-dependent. Glob. Change Biol. 14, 2661-2677. doi: 10.1111/j.1365-2486.2008.01672.x

Zagmajster, M., Malard, F., Eme, D., and Culver, D. C. (2018). "Subterranean biodiversity patterns from global to regional scales," in Cave Ecology, eds O. T. Moldovan, L. Kováč, and S. Halse (Cham: Springer).

Zhang, D. Q., Hui, D. F., Luo, Y. Q., and Zhou, G. Y. (2008). Rates of litter decomposition in terrestrial ecosystems: global patterns and controlling factors. J. Plant Ecol. 1, 85-93. doi: 10.1093/jpe/rtn002

Zhang, M. H., Cheng, X. L., Geng, Q. H., Shi, Z., Luo, Y. Q., and Xu, X. (2019). Leaf litter traits predominantly control litter decomposition in streams worldwide. Glob. Ecol. Biogeogr. 28, 1469-1486. doi: 10.1111/geb.12966

Conflict of Interest: The authors declare that the research was conducted in the absence of any commercial or financial relationships that could be construed as a potential conflict of interest.

Copyright (c) 2020 Ravn, Michelsen and Reboleira. This is an open-access article distributed under the terms of the Creative Commons Attribution License (CC BY). The use, distribution or reproduction in other forums is permitted, provided the original author(s) and the copyright owner(s) are credited and that the original publication in this journal is cited, in accordance with accepted academic practice. No use, distribution or reproduction is permitted which does not comply with these terms. 